Kong. Res. J. 1(2): 65-67, 2014

Kongunadu Arts and Science College, Coimbatore

\title{
BIOPHARMACOLOGICAL EFFECTS OF EXTRACTS OF SOME COMMONLY AVAILABLE INDIAN PLANTS ON CHANNA STRIATA
}

\author{
Binukumari, S.* and J. Vasanthi \\ Department of Zoology, Kongunadu Arts \& Science College, Coimbatore. \\ *E-mail: binu.kumari@rediffmail.com
}

\begin{abstract}
Six commonly available Indian plants extracts on Channa striata indicate that acetylcholine synthesis and acetylcholinesterase inhibition were observed in the heart, brain, muscle and liver tissues. The possibility of using the toxic substances as fish bait is discussed.
\end{abstract}

Key words : Acetylcholine, Acetylcholinesterase, Channa striata.

\section{INTRODUCTION}

Many Indian plants have been increasingly tested for a wide variety of biological activities including antifertility, anticancer, chemotherapeutic and pharmacological activities (Agarwal and Rangari. 2003: Bol Kent et al., 2004).However, most of these studies were done only on mammals.

Though various plant extract are used as arrow poisons and fish baits,no study to date has evaluated the biopharmocological properties of these plant extracts on fresh water food fishes. In order to identify a substance which can be easily obtained and readily used for fish hatching purposes. We have evaluated to pharmacological effects of six commonly available poisonous plants in our area.

\section{MATERIALS AND METHODS}

\subsection{Collection of Plants}

The following plants are collected and tested.

\begin{tabular}{|c|c|c|}
\hline Plant & Family & $\begin{array}{l}\text { Parts } \\
\text { Used }\end{array}$ \\
\hline $\begin{array}{l}\text { Datura metel } \\
\text { Gloriosa superb } \\
\text { Vinca rosea } \\
\text { Calotropis gigantean } \\
\text { Antiarchis toxicaria } \\
\text { Parthenium } \\
\text { hysterophorus }\end{array}$ & $\begin{array}{l}\text { Solanaceae } \\
\text { Liliaceae } \\
\text { Apocynaceae } \\
\text { Asclepiadaceae } \\
\text { Moraceae } \\
\text { Compositae }\end{array}$ & $\begin{array}{l}\text { Seeds } \\
\text { Roots } \\
\text { Leaves } \\
\text { Leaves } \\
\text { Leaves } \\
\text { Leaves }\end{array}$ \\
\hline
\end{tabular}

\subsection{Procurement of fingerlings}

These plants were screened for pharmacological effects in the commonly available and economically important freshwater food fish Channa Striata. The fishes (10-25g) were procured from local freshwater sources and held in laboratory in large plastic tanks (02: 6-7 mg/I; pH 6.7-6.9; fish density 8-15 g/I water) for 15 days before using in the experiments.Fishes were subjected to $50 \%$ ethanolic extracts for 30 days.The level of plant extract was kept constant by changing the water everyday and adding the requistic amount of plant extract stock solution.They were fed daily prior to change of water to prevent ingestion of plant extract through food. A control group exposed to ethanol alone was also maintained. At the end of 30 day period, the fish were killed by decapitation and the tissues rapidly excised. The tissues were raised,blotted and homogenized in a motor driven all glass homogenizer with two volumes of chilled saline $(0.7 \% \mathrm{Nacl})$. Homogenates were centrifuged at $10,000 \mathrm{~g}$ for $15 \mathrm{~min}$. The supernatant fraction were diluted with ten volumes of chilled saline and used as the enzyme source.

\subsection{Determination of Biopharmacological activity}

The activities of acetylcholinesterase were determined according to the methods of Bock endahl and Ammon (1955) using 4.5 x 10-2 M acetylcholine as substrate.The acetylcholine content was determined after Metcalf (1951) and proteins by the method of Lowry et al. (1951). The different sets of data were examined for significant difference $(\mathrm{P}<0.05)$ by Wilcoxans two-sample test (Hodges and Lehman, 1970).

\section{RESULTS AND DISCUSSION}

\subsection{Inhibition of Biopharmacological activity}

The results are presented in the Table 1 and Table 2. From the results it is clear that acetylcholine in accumulated significantly and acetylcholinesterase is inhibited in the heart, brain, muscle and liver tissues of C.striata. Maximum inhibition is recorded for Parthenium and Datura. The accumulation of acetylcholine indicate the blockage of nerve impulse transmission. The rapid depletion of acetylcholinesterase again show the disruption of neuromuscular transmission. 


\subsection{Types of toxins in plants}

All the six plants extracts contain potent toxic substances and inhibit the functioning of the nervous system.According to Viswanathan and Joshi (1983), some of the toxic substances present in the tested plants are

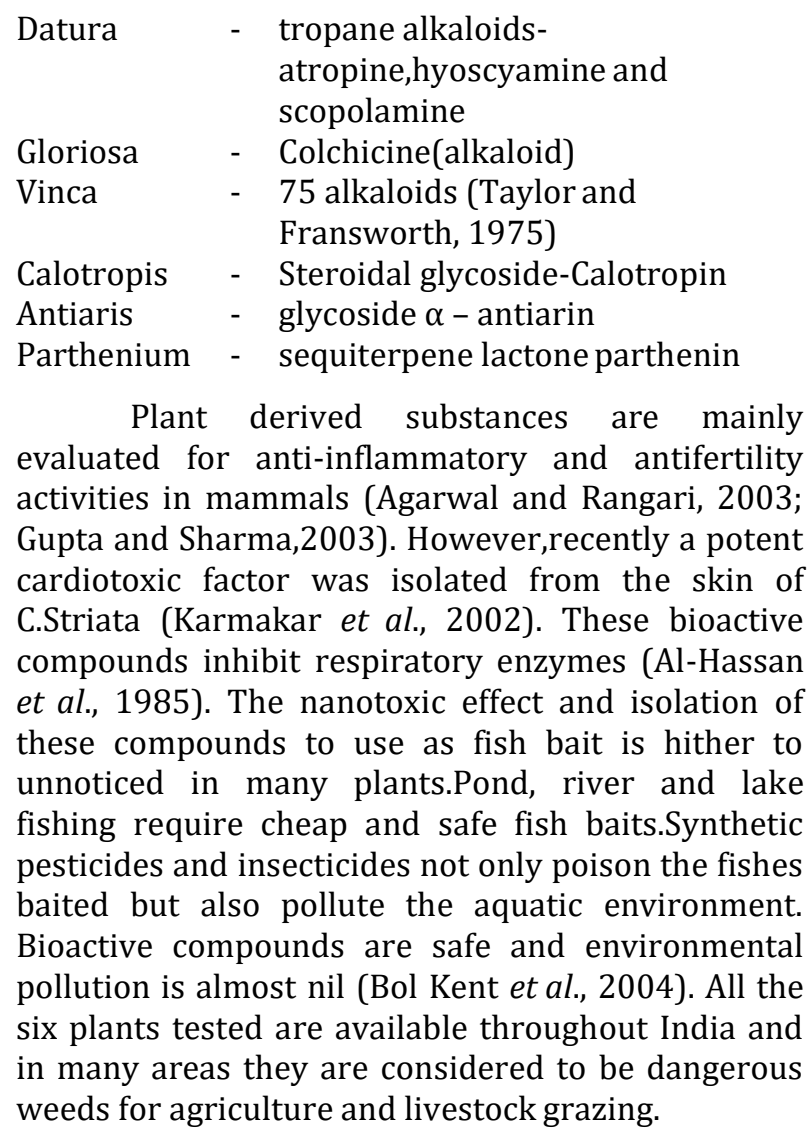

\section{CONCLUSION}

The toxic substances present in the six plants inhibit the neuromuscular transmission. These toxic substances accumulate in the fish metabolism and cause neural problems to the people those who consume it. Therefore, proper arrangements have to be taken by the government and volunteers to eradicate the unwanted weeds from the crops and agriculture field.

\section{REFERENCES}

Agarwal, R.B. and V.D. Rangari, (2003). Phytochemical investigation and evaluation of anti-inflammatory and anti-arthritic activities of essential oil of Strobilanthus ixiocephala Banth. Indian. J. Exp. 41: 890-894.

Al-Hassan, J.M., M. Ali, M. Thomson, T. Fatima and J. Gubler, (1985). Toxic effects of the soluble secretion from the Arabian Gulf Catfish (Avius thalassinus, Ruppell) on plasma and liver enzyme level. Toxicon. 532.

Bockendahl, H. and R. Ammon, (1955). In Methods of Enzymatic Analysis. Academic Press.New York, 772.

Bolkent, S., N. Alev, N. Ozsoy, M.S. Inceli, A. Caw, A. Kyar and R.Y. Yanardag, (2004). Effects of Aloe Vera Burn. Fil. Leaf gel and pulp extracts on kidney in type-II diabetic rat models. Indian J.Exp.Biol.42: 48-52.

Gupta, R.S. and A. Sharma, (2003). Antifertility effect of Tinospora Cordifolia (Willd).Stem extract in male rats. Indian J.Exp.Biol. 41: 885-889.

Hodges, J.L. and E.L. Lehman, (1971). Basic Concepts of Probability Statistics.Holden- Day, San Francisco. 441.

Kamakar, S., S.C. Dasgupta and A. Gomes, (2002). Pharmacological and haematological study of shol fish (Channa striatus) skin extract on experimental animal Indian. J. Exp. Biol. 40: 115-118.

Lowry, OH., N.J. Rosebrough, A.L. Farr and R.J. Randall, (1951). Protein measurement with the folin phenol reagent. J. Biol. Chem. 193: 365375.

Matcalf, R.L. (1951). In: Methods in Biochemical Analysis Inter Science Publications New York.

Taylor, W.I. and N.R. Farnsworth, (1975). The Catharanthus Alkaloides. Marcel Dekkar, New York.

Viswanathan, N. and B.S. Joshi, (1983). Toxic Constituents of some Indian plants. Curr.Sci. 52: $1-8$. 
Table 1.Effects of Plant Extracts on the Acetylcholinesterase and Acetylcholine Activities in the Heart and Brain of C.Striata

\begin{tabular}{|c|c|c|c|c|c|c|c|c|}
\hline & \multicolumn{4}{|c|}{ Heart } & \multicolumn{4}{|c|}{ Brain } \\
\hline & \multicolumn{2}{|c|}{ AchE } & \multicolumn{2}{|c|}{ Ach } & \multicolumn{2}{|c|}{ AchE } & \multicolumn{2}{|c|}{ Ach } \\
\hline & Control & Exp & Control & Exp & Control & Exp & Control & Exp \\
\hline Datena & \multicolumn{2}{|c|}{-34.51} & \multicolumn{2}{|c|}{-181.11} & \multicolumn{2}{|c|}{-71.19} & \multicolumn{2}{|c|}{+177.75} \\
\hline \multirow[t]{2}{*}{ Gloriosa } & $37.41 \pm 2.88$ & $27.50 \pm 2.61$ & $24.51 \pm 2.76$ & $65.19 \pm 3.06$ & $76.12 \pm 5.01$ & $23.82 \pm 2.19$ & $28.63 \pm 3.40$ & $66.41 \pm 3.00$ \\
\hline & \multicolumn{2}{|c|}{-26.49} & \multicolumn{2}{|c|}{+165.97} & \multicolumn{2}{|c|}{-68.71} & \multicolumn{2}{|c|}{+131.96} \\
\hline Vinca & $37.41 \pm 2.88$ & $22.41 \pm 0.89$ & $24.51 \pm 2.76$ & $70.65 \pm 4.16$ & $76.12 \pm 5.01$ & $20.43 \pm 3.01$ & $28.63 \pm 3.40$ & $82.40 \pm 3.93$ \\
\hline Calotropis & \multicolumn{2}{|c|}{-40.10} & \multicolumn{2}{|c|}{+188.25} & \multicolumn{2}{|c|}{+70.16} & \multicolumn{2}{|c|}{+181.81} \\
\hline Antiarcis & $37.41 \pm 2.88$ & -34.06 & +175.44 & $\begin{array}{l}67.51 \pm 3.08 \\
4\end{array}$ & -70.56 & 6 & $28.63 \pm 3.40$ & $78.43 \pm 4.00$ \\
\hline Parthenium & $37.41 \pm 2.88$ & $20.61 \pm 2.90$ & $\begin{array}{r}24.51 \pm 2.76 \\
+1\end{array}$ & $\begin{array}{l}72.36 \pm 4.08 \\
3\end{array}$ & $76.12 \pm 5.01$ & 3 & $\begin{array}{r}28.63 \pm 3.40 \\
+1\end{array}$ & $\begin{array}{l}82.19 \pm 42.1 \\
8\end{array}$ \\
\hline
\end{tabular}

Value expressed as mean \pm SD of 6 observations are significant $p<0.001$

Table 2. Effects of Plant Extracts on the Acetylcholinesterase and Acetylcholine Activities in the Muscle and Liver of C.Striata

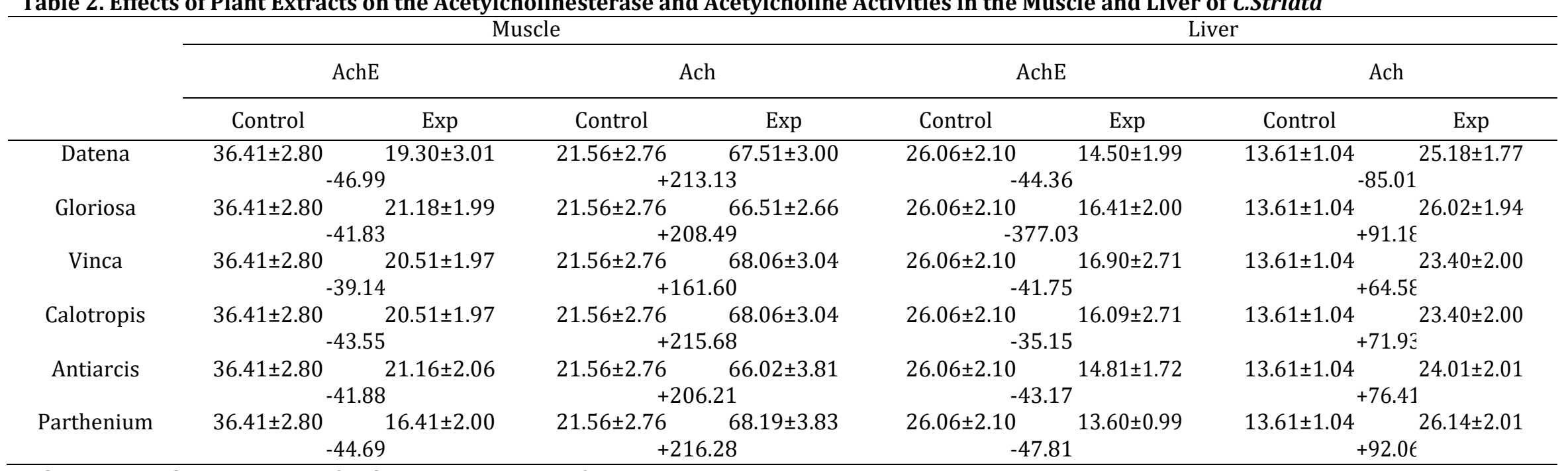

Value expressed as mean \pm SD of 6 observations are significant $\mathrm{p}<0.001$ 